\title{
Phytochemicals Screening, Phenolic Estimation and Evaluation for Anti-Oxidant, Anti-Inflammatory and Anti-Microbial Activities of Sequentially Soxhlet Extracted Coconut Testa
}

\author{
Sashi Bhusan Ojha, Shaktirekha Roy, Soumya Das, Gunanidhi Dhangadamajhi \\ Department of Biotechnology, North Orissa University, Baripada, Odisha, India \\ Email: gunarmrc@gmail.com
}

How to cite this paper: Ojha, S.B., Roy, S., Das, S. and Dhangadamajhi, G. (2019) Phytochemicals Screening, Phenolic Estimation and Evaluation for Anti-Oxidant, Anti-Inflammatory and Anti-Microbial Activities of Sequentially Soxhlet Extracted Coconut Testa. Food and Nutrition Sciences, 10, 900-922.

https://doi.org/10.4236/fns.2019.108065

Received: June 25, 2019

Accepted: August 9, 2019

Published: August 12, 2019

Copyright $\odot 2019$ by author(s) and Scientific Research Publishing Inc. This work is licensed under the Creative Commons Attribution International License (CC BY 4.0).

http://creativecommons.org/licenses/by/4.0/

\section{(c) (i) Open Access}

\begin{abstract}
Background: In many coconut industries, the outer layer of thin brown skin of coconut kernel known as testa is peeled out as a byproduct. Despite the testa is rich in fat and plenty of polyphenolic compounds, it has been underutilized either as animal feed, serving as raw materials for bio-diesel production or discarded directly. Anticipating coconut testa (CT) as a natural source of multiple phyto-chemicals, its exploitation for the pharmacological activity or utilization as value added product is required which may reduce the disposal costs as well. Methods: Secondary metabolites from CT were extracted sequentially with different organic solvents based on polarity in the soxhlet apparatus followed by extraction with sterilized water. The crude dried extracts thus prepared were evaluated for qualitative screening of phytochemicals and quantitative estimation of total phenols, flavonoids and tannin content. Moreover, the antioxidant, anti-inflammatory and anti-microbial activities were also investigated. Results: Phytochemicals screening revealed the presence of polyphenolic compounds in methanolic fraction including phenols $(822.60 \pm 16.36 \mathrm{mg} / \mathrm{g})$, flavonoids $(103.30 \pm 9.78 \mathrm{mg} / \mathrm{g})$ and tannin $(663.50 \pm$ $19.26 \mathrm{mg} / \mathrm{g}$ ), whereas non-phenolic compounds were present in other fractions. While methanolic fraction showed invariably the highest anti-oxidant activity in multiple assay methods, non-phenolic compounds in aqueous and chloroform fractions exhibited high anti-inflammatory activity. Antimicrobial activity was observed by both phenolic and non-phenolic compounds. Conclusion: The findings of the study reveal that CT is a rich source of various polyphenolic and non-phenolic natural antioxidants, anti-inflammatory and antimicrobial compounds. These findings are promising and form the basis to identify the number of active components and their characterization.
\end{abstract}




\section{Keywords}

Coconut Testa, Phytochemicals, Anti-Oxidant, Anti-Inflammatory, Anti-Microbial, Soxhlet Extraction

\section{Introduction}

Coconut (Cocos nucifera L.) belongs to the family Arecaceae [Palmae] and the subfamily Cocoideae is an important monocotyledon plant widely grown in the tropic and sub-tropics [1]. Further, certain religious and traditional values of coconut in most parts of India and other South East Asian countries have fared the production and productivity of coconut in these countries much better than many other countries. The coconut palm is sometimes referred to as 'great nut of India' owing to the use of all of its parts in some way or the other in coconut-growing areas. Apart from the use of coconut water, the natural sterile liquid from the young immature coconuts as a beverage; the kernel is used as the source of food and oil. Further, the wastes such as shell or coir are also used as raw materials for many industries for the production of shell-activated carbon or fibers for car seats and other household materials [2] [3] [4]. With the increasing demand for coconut oil, preparation of desiccated coconut powder or other products such as coconut cream and milk powder, the thin brown skin of coconut kernel known as testa is peeled out and processed in many coconut industries and the byproduct testa is usually underutilized. Of the more than 93 countries growing coconut Worldwide, India ranks $3^{\text {rd }}$ by producing about 12,000 14,000 metric tons coconut annually, which contributes to about $19.3 \%$ of total coconut production of the World [5]. In an estimate, it has observed that the coconut testa (CT) constitutes about $18 \%$ of the total dry weight of kernel [6] and that about 23.7 thousand tons testa are produced in Hainan Island annually [4]. The worldwide production of this waste is even more and requires alternative ways for its re-utilization as valuable products. Several studies have been conducted to assess the bio-active potential or nutritional value of coconut testa. Studies have shown that the testa is rich in fat [7] and contains plenty of polyphenolic compounds with a potent antioxidant capacity [8] [9]. Polyphenolic compounds ranging from simple phenolic acids to polyphenols such as flavonoids, tannins, anthocyanins, etc. are important plant derived phytochemicals which have anti-oxidant and anti-ageing property and have been shown to improve physical fitness or degenerative diseases like cancer, diabetes, hypertension and cardiovascular problems [10] [11] [12] [13]. However, the use of testa is largely limited either as an animal feed [14], serving as raw material for bio-diesel production [15] or discarded directly despite being a rich source of polyphenol compounds. The fact that plant secondary metabolites including polyphenolic compounds being diverse, different classes of compounds are soluble only in specific solvent system [16] and the extraction yields depends on methods adopted, nature 
of plant materials and presence of various compounds [17] [18] [19]. A previous study examining for identification of suitable solvent system for maximum extractability from the coconut testa has revealed significant differences in total phenolic content (TPC) and total flavonoid content (TFC) with antioxidant potential in various solvent systems studied [9]. However, to date, only ethanolic extract of defatted coconut testa has been analyzed for the qualitative and quantitative determination of phytochemicals [20]. Moreover, the ethanolic extract of testa has been found to possess anti-hyperglycaemic activity [8], exhibit inhibition effect on the oxidation of human low-density lipoprotein [21] or evaluated for cosmeceutical potentials [22] [14]. Further, the ethanolic extract of coconut testa has been shown to contain more natural anti-oxidants compared to kernel oil [20]. The oil extracts of testa have also been proved to be protective against oxidative damage induced by reactive oxygen species [23] [21]. Despite the fact of testa as a natural source of multiple phyto-chemicals, its exploitation for potential human health benefits is yet to be achieved. Utilization of coconut testa as value added product may have the economic and environmental impacts of reducing the disposal costs.

Therefore, in the present study secondary metabolites from coconut testa (CT) were extracted sequentially using organic solvents [Petrolium benzene, chloroform, ethyl acetate and methanol] and water based on polarity in soxhlet apparatus and evaluated for qualitative screening of phytochemicals. Besides, with the aim at exploring the potential benefit, the different solvent extracts of coconut testa were evaluated for quantitative estimation of total phenols, flavonoids and tannin content. Moreover, the antioxidant activity, anti-inflammatory activity and anti-microbial activity were also investigated.

\section{Materials and Methods}

\subsection{Collection of Sample}

Healthy coconuts were collected in sterile plastic bags from the different locality of Baripada, Mayurbhanj, Odisha and processed to peel off the thin, brown outer covering of kernel called the testa with the help of a scraper. These peeled off testa were then allowed to shed dry for 10 - 15 days followed by pulverization into coarse powder using the blender.

\subsection{Extraction of Metabolites from Selected Plant Parts}

The powdered coconut testa (CT) of about $30 \mathrm{gm}$ was used for crude extract preparation by sequential extraction with different solvents of $300 \mathrm{ml}$ based on polarity [such as petroleum benzene, chloroform, ethyl acetate and methanol] using soxhlet apparatus at $50^{\circ} \mathrm{C}$ and for 12 cycles for extraction with each solvent. The aqueous extract was prepared by mixing the dried, left out CT after methanol extraction with sterilized water at $200 \mathrm{rpm}$ in room temperature (RT) for 16 - 18 hours. The solvent extracts thus obtained were then allowed to evaporate in RT nearly for 15 - 20 days or till complete evaporation was ensured. The crude dried extracts of various solvents were then collected in sterile vials, 
labeled and kept at RT until further use.

\subsection{Phytochemical Screening}

Preliminary qualitative screening for the presence of various phytochemicals was carried out using the protocols of Sheel et al. [24], Nanna et al. [25], Mishra et al. [26], and Sharma et al. [27].

\subsection{Estimation for Total Phenolic Content}

The total phenolic content in various solvent fractions of CT was determined based on Ebrahimzadeh et al. [28], with partial modification. Briefly, each of the solvent extracts and gallic acid was reconstituted to a concentration of $1 \mathrm{mg} / \mathrm{ml}$ with $10 \%$ DMSO in distilled water, except for aqueous extract which was dissolved with water only. Then, $1 \mathrm{ml}$ of various concentrations of gallic acid [100 $500 \mu \mathrm{g} / \mathrm{ml}$ at $100 \mu \mathrm{g}$ interval] in distilled water was mixed with $5 \mathrm{ml}$ of Folin-Ciocalteau's (FC) phenol reagent [diluted to 10 fold with water]. After 3 minutes, $4 \mathrm{ml}$ of $7.5 \%[\mathrm{w} / \mathrm{v}] \mathrm{Na}_{2} \mathrm{CO}_{3}$ in water was added to the mixture and incubated in dark for $20 \mathrm{~min}$ at room temperature $\left[25^{\circ} \mathrm{C}\right]$. Similarly, $1 \mathrm{ml}[100 \mu \mathrm{g} / \mathrm{ml}]$ of various solvents extract in triplicates was processed. The absorbance was read against the blank containing $\mathrm{FC}$ reagent, $\mathrm{Na}_{2} \mathrm{CO}_{3}$ and water without any extract or gallic acid at $760 \mathrm{~nm}$. A calibration curve was constructed from the absorbance of known concentrations of Gallic acid. TPC was calculated from the calibration equation for gallic acid $\mathrm{y}=0.006 \mathrm{x}+0.348, \mathrm{R}^{2}=0.976$ [where $\mathrm{y}$ is absorbance and $\mathrm{x}$ is the concentration of gallic acid in $\mu \mathrm{g} / \mathrm{ml}$ ] for each extract in triplicates and expressed as mg of gallic acid equivalents [mg GAE]/g of plant extract.

\subsection{Estimation for Total Flavonoid Content}

The total flavonoid content was determined by the Aluminum chloride colorimetric method described by Islam et al. [29], with minor modification as detailed below. Quercetin was used instead of gallic acid as standard. Dilution of plant extracts and quercetin were carried out as mentioned previously in this paper for total phenol estimation. To $0.5 \mathrm{ml}$ of various concentration of quercetin [25 - $400 \mu \mathrm{g} / \mathrm{ml}$ at two fold dilution] and plant extracts [100 $\mu \mathrm{g} / \mathrm{ml}$ ], $1.5 \mathrm{ml}$ of $95 \%$ ethanol was added followed by addition of $0.1 \mathrm{ml}$ of $10 \%$ aluminum chloride and $0.1 \mathrm{ml}$ of $1 \mathrm{M}$ potassium acetate buffer. Then, $2.8 \mathrm{ml}$ of distilled water was added to the reaction mixture and it was incubated for $30 \mathrm{~min}$ at room temperature, after which its absorbance was read at $415 \mathrm{~nm}$ against the blank [which does not contain either quercetin or CT extract]. A calibration curve was constructed from the absorbance of different known concentrations of Quercetin. TFC was calculated from the calibration equation for quercetin $y=0.004 x+0.103, R^{2}=0.996$ and the results were expressed as $\mathrm{mg}$ of quercetin equivalents per $\mathrm{g}$ of extract.

\subsection{Estimation for Total Tannin Content [TTC]}

The total tannin content in each of the solvent fraction of CT was determined 
following the protocol of Makker et al. [30], with modification as described. Briefly, $1 \mathrm{ml}$ of various concentration of tannic acid [3.125 - $100 \mu \mathrm{g} / \mathrm{ml}$ with two fold dilution] or triplicate solvent extracts $[50 \mu \mathrm{g} / \mathrm{ml}]$ in $50 \%$ methanol were mixed with $2 \mathrm{ml}$ of $1 \mathrm{mg} \mathrm{BSA} / \mathrm{ml}$ in acetate buffer [0.2 M, PH 4.8]. The blank had $1 \mathrm{ml}$ of $50 \%$ methanol mixed with $2 \mathrm{ml}$ BSA. After incubation at RT for 30 minutes, these were centrifuged at $3000 \mathrm{~g}$ for 15 minutes. The supernatant was discarded in all and to the pellet $1 \mathrm{ml}$ of $1 \%$ SDS, $3 \mathrm{ml}$ of $7 \%$ triethanolamine in $1 \%$ SDS and $1 \mathrm{ml}$ of ferric chloride $[0.01 \mathrm{M}$ in $0.1 \mathrm{M} \mathrm{HCl}]$ were added. This was followed by incubation at RT for 30 minutes and the absorbance was recorded at $510 \mathrm{~nm}$ against the blank. From the calibration curve constructed by absorbance of different known concentrations of tannic acid, TTC was calculated from the equation for tannic acid $\mathrm{y}=0.002 \mathrm{x}+0.085, \mathrm{R}^{2}=0.994$ and expressed as $\mathrm{mg}$ of tannic acid equivalents per $\mathrm{g}$ of solvent extract.

\subsection{In Vitro Antioxidant Activity}

\subsubsection{DPPH Assay}

The scavenging activity of different solvent extracts to DPPH [2,2-diphenyl-1-picryl hydrazyl] radical was measured following the method as described in Chang et al. [31], with slight modification. About $1.5 \mathrm{ml}$ of different concentrations of test extract [3.125 - $100 \mu \mathrm{g} / \mathrm{ml}]$ in $10 \%$ DMSO was mixed with $1.5 \mathrm{ml}$ of DPPH [0.1 $\mathrm{mM}$ ] solution in methanol. A mixture containing the equal volume of DPPH and $10 \%$ DMSO served as control. The samples were incubated in dark at RT for 30 minutes and absorbance was recorded at $517 \mathrm{~nm}$ against methanol as a blank. Ascorbic acid, gallic acid, quercetin, tannic acid and BHT were taken as positive controls. Percent DPPH inhibition was calculated using the following formula:

$$
\% \mathrm{DPPH} \text { inhibition }=[\{\mathrm{OD}[\text { control }]-\mathrm{OD}[\text { sample }]\} / \mathrm{OD}[\text { control }]] \times 100
$$

\subsubsection{ABTS Assay}

The ABTS [2,2'-Azino-bis-[3-ethyl]benzothiazoline]-6-sulfonic acid diammonium salt] assay was carried out following the method described in Re et al. [32]. Briefly, the reaction was initiated by adding $0.3 \mathrm{ml}$ of various concentrations [3.125 $-100 \mu \mathrm{g} / \mathrm{ml}$ at two fold dilution] of solvent extracts in 10\% DMSO with $2.7 \mathrm{ml}$ of diluted ABTS [prepared by reacting $7 \mathrm{mM}$ ABTS and $2.45 \mathrm{mM}$ potassium persulfate at room temperature in the dark for $16 \mathrm{~h}$ and the ABTS working solution was obtained by further dilution with methanol to give an absorbance of $0.85 \pm 0.20$ at $734 \mathrm{~nm}$ ]. The control sample had $0.3 \mathrm{ml}$ of $10 \%$ DMSO mixed with $2.7 \mathrm{ml}$ of ABTS. The absorbance was read at $734 \mathrm{~nm}$ against a blank [a mixture of $10 \%$ DMSO and ethanol] after 60 minutes of incubation in dark at RT. The percentage of inhibition was calculated using Equation (1). Ascorbic acid, gallic acid, tannic acid, quercetin and BHT were used as positive controls.

\subsubsection{Phosphomolybdate Assay}

Phosphomolybdate assay was carried out by the method proposed by Prieto et al. [33]. To $0.4 \mathrm{ml}$ of various concentrations of [3.125 - $100 \mu \mathrm{g} / \mathrm{ml}$ ] of different 
solvent extracts of CT in 10\% DMSO, $4 \mathrm{ml}$ of phosphomolybdate reagent $[0.6 \mathrm{M}$ sulphuric acid, $28 \mathrm{mM}$ sodium phosphate and $4 \mathrm{mM}$ ammonium molybdate] was added. The control sample had $0.4 \mathrm{ml} \mathrm{10 \%} \mathrm{DMSO/} \mathrm{distilled} \mathrm{water} \mathrm{[for} \mathrm{as-}$ corbic acid/aqueous extract] instead of solvent extract. The test tube containing the reaction mixtures were covered with aluminum foil and incubated at $95^{\circ} \mathrm{C}$ for 90 minutes. The mixture was then allowed to cool down to room temperature and the absorbance was recorded at $695 \mathrm{~nm}$ against the blank. Blank was run using the same procedure, which had either $10 \%$ DMSO or water [for ascorbic acid/aqueous extract]. The reductions of Mo [VI] to Mo [V] by various solvent fractions of coconut testa were calculated as ascorbic acid equivalent.

\subsubsection{Metal Chelating Assay}

The metal chelating assay was carried out by the method reported in Dinis et al., [34]. In this method, to $1 \mathrm{ml}$ of various concentrations [312.5 - 10,000 $\mu \mathrm{g} / \mathrm{ml}$ in two fold dilution] of solvent extract, $0.5 \mathrm{ml}$ of $2 \mathrm{M}$ ferrous chloride and $2 \mathrm{ml}$ of 5 $\mathrm{mM}$ ferrozine solution were added. The solution was mixed thoroughly and incubated in dark at room temperature for 10 minutes. The control was run in the same process except that distilled water replaced solvent extract. The absorbance was read at $562 \mathrm{~nm}$ against distilled water as a blank. EDTA was used as a standard metal chelator. Percent of inhibition was calculated using Equation (1).

\subsubsection{Reducing Power Assay}

Antioxidant capacities of different solvent fractions of CT were measured in reducing power assay according to a method reported by Oyaizu, [35]. To $1 \mathrm{ml}$ of each of the solvent extracts of various concentrations [62 - $1000 \mu \mathrm{g} / \mathrm{ml}$ in two fold dilution] in 10\% DMSO, $2.5 \mathrm{ml}$ of sodium phosphate buffer [ $\mathrm{PH} \mathrm{6.6]}$ and $2.5 \mathrm{ml}$ of potassium ferricyanide $[1 \% \mathrm{w} / \mathrm{v}]$ were added and mixed well. After incubation for 20 minutes at $50^{\circ} \mathrm{C}, 2.5 \mathrm{ml}$ of trichloroacetic acid was added and the whole mixture was centrifuged at $3000 \mathrm{rpm}$ for 10 minutes. To $2.5 \mathrm{ml}$ of the supernatant, $2.5 \mathrm{ml}$ of distilled water and $0.5 \mathrm{ml}$ of ferric chloride $[0.1 \% \mathrm{w} / \mathrm{v}$ in distilled water] solution were added and the absorbance was measured at $700 \mathrm{~nm}$ against the blank. Blank for each solvent extract was run using the same procedure but replacing the extracts with an equal volume of solvent [10\% DMSO or water]. Quercetin and ascorbic acid were used as positive controls

\subsubsection{CUPRAC Assay}

CUPRAC assay was carried out according to the method proposed by Karaman et al. [36]. $1 \mathrm{ml}$ of Cupric chloride [10 $\mathrm{mM}$ ] solution added with equal volume of freshly prepared ethanolic neocuproine $[7.5 \mathrm{mM}]$ solution and ammonium acetate buffer [ $1 \mathrm{M}, \mathrm{PH}=7]$ were mixed thoroughly with $0.5 \mathrm{ml}$ of different concentrations of each of the solvent extract of CT [62.5 - $1000 \mu \mathrm{g} / \mathrm{ml}]$. Then, the total volume of the reaction mixture in each of the test tube was adjusted to 5.0 $\mathrm{ml}$ with distilled water and mixed well. The tubes were stoppered and kept at room temperature. Absorbance was measured at $450 \mathrm{~nm}$ against a reagent blank after $30 \mathrm{~min}$. Ascorbic acid and quercetin were used as positive controls. In- 
creased absorbance of the reaction mixture in reducing power assay and CUPRAC assay indicates increased reduction capability.

\subsection{Antimicrobial Activity}

The test pathogens such as two bacterial strains, Escherichia coli [MTCC 443] and Staphylococcus aureus [MTCC 737] and one fungal pathogen, Candida albicans [MTCC 227] were obtained from Institute of Microbial Technology [IMTECH] Chandigarh, India. Antimicrobial activity was carried out by agar cup method [37] in Nutrient agar [NA] plates for bacteria and in potato dextrose agar [PDA] plates for fungi. The overnight grown pathogens were diluted with sterile saline $[0.85 \% \mathrm{NaCl}]$ and the absorbance was adjusted to $0.08-0.12$ at 625 $\mathrm{nm}$ [which corresponds to $(1-2) \times 10^{8} \mathrm{CFU} / \mathrm{ml}$ of bacteria or $(1-5) \times 10^{6}$ $\mathrm{CFU} / \mathrm{ml}$ of $C$. albicans]. About $100 \mu \mathrm{l}$ of these microbial suspensions were spread on to the entire surface of respective plates. Then, a hole [6-8 mm] was punched with a sterile tip and $100 \mu \mathrm{l}$ of different solvent extracts $[10 \mathrm{mg} / \mathrm{ml}]$ and standard antibiotics such as Azithromycin for bacteria $[10 \mu \mathrm{g} / \mathrm{ml}]$ and Fluconazole for fungi $[10 \mu \mathrm{g} / \mathrm{ml}]$ were introduced into these wells. All these activities were carried out in aseptic condition in a laminar air hood. Following this, the plates were incubated at $37^{\circ} \mathrm{C}$ for 24 hours and the zone of inhibition was measured in $\mathrm{mm}$.

\subsection{In Vitro Anti-Inflammatory Activity}

The anti-inflammatory activity was assessed by membrane stabilization of heat induced or hypotonic induced haemolysis of human RBCs as per the method described in Shinde et al. [38] and inhibition of heat induced albumin denaturation following the protocol of Mizushima et al. [39] with some minor modifications.

\subsubsection{Preparation of HRBC Suspension}

About $3 \mathrm{ml}$ of blood from a healthy volunteer was freshly collected in a heparinized vial and centrifuged at $1000 \mathrm{rpm}$ for about 2 minutes at RT. After removal of supernatant, to the red blood cell pellet equal volume of isotonic solution [154 $\mathrm{mM} \mathrm{NaCl}$ in $10 \mathrm{mM}$ sodium phosphate buffer, where the later contains $0.26 \mathrm{~g}$ of $\mathrm{NaH}_{2} \mathrm{PO}_{4} \cdot 2 \mathrm{H}_{2} \mathrm{O}, 1.15 \mathrm{~g}$ of $\mathrm{Na}_{2} \mathrm{HPO}_{4}$ and $9.0 \mathrm{~g}$ of $\mathrm{NaCl}$ in 1 litre of water] of $\mathrm{pH}$ 7.4 was added, mixed gently and centrifuged at 1000 rpm for 2 minutes. Following this, the supernatant was discarded and the process was repeated twice. Finally, the RBC pellet was reconstituted to a $10 \%[\mathrm{v} / \mathrm{v}]$ suspension with normal saline $[0.9 \% \mathrm{NaCl}]$ and kept at $4{ }^{\circ} \mathrm{C}$ until further use.

\subsubsection{Heat Induced Haemolysis}

The plant extracts and control drug ibuprofen were constituted to $1 \mathrm{mg} / \mathrm{ml}$ with $10 \%$ DMSO in normal saline. Eleven centrifuge tubes of $15 \mathrm{ml}$ capacity were taken, 10 were made into two sets of five centrifuge tubes, labeled as 1 to 5 in each set. In each set, $2 \mathrm{ml}$ of isotonic solution was mixed with $2 \mathrm{ml}$ of plant extract of various concentrations [0.062 $-1 \mathrm{mg} / \mathrm{ml}$ with two fold dilutions] and 0.5 
$\mathrm{ml}$ of $10 \%$ HRBC solution. In tube $0.2 \mathrm{ml}$ of normal saline was taken instead of plant extract, which served as a control sample. One set including the tube labeled with 0 was incubated at $40^{\circ} \mathrm{C}$ [heated sample] while another set was at $4^{\circ} \mathrm{C}$ [unheated sample]. After 20 minutes of incubation, these samples were centrifuged for 10 minutes at $1000 \mathrm{rpm}$ in RT and the absorbance of supernatant was recorded against the blank [normal saline] at $540 \mathrm{~nm}$. This process was carried out twice for each of the solvent extracts of CT and ibuprofen. The percentage inhibition of haemolysis was calculated as

$$
1-\frac{\mathrm{OD}_{2}-\mathrm{OD}_{1}}{\mathrm{OD}_{3}-\mathrm{OD}_{1}} \times 100
$$

where $\mathrm{OD}_{1}=$ Absorbance of test sample unheated, $\mathrm{OD}_{2}=$ absorbance of test sample heated and $\mathrm{OD}_{3}=$ absorbance of control sample heated.

\subsubsection{Hypotonic Induced Haemolysis}

In hypotonic induced haemolysis of HRBC also, 11 number of centrifuge tubes of $15 \mathrm{ml}$ capacity were taken and named as described for heat induced haemolysis. However, in one set labeled as $1-5,2 \mathrm{ml}$ of different concentrations of the solvent extract $[0.062-1 \mathrm{mg} / \mathrm{ml}]$ were taken while in another set, $2 \mathrm{ml}$ of ibuprofen of corresponding concentration $[0.062-1 \mathrm{mg} / \mathrm{ml}]$ were taken. $2 \mathrm{ml}$ of normal saline was taken in a centrifuge tube labeled as " 0 ". In all these eleven centrifuge tubes, $2 \mathrm{ml}$ of hypotonic solution $[50 \mathrm{mM} \mathrm{NaCl}$ in $10 \mathrm{mM}$ sodium phosphate buffer] was added followed by the addition of $0.5 \mathrm{ml}$ of $10 \%$ HRBC solution. After 10 minutes of incubation at RT, these were centrifuged at 1000 rpm for 10 minutes and the absorbance of the supernatant was recorded against the blank [normal saline] at $540 \mathrm{~nm}$.

The percentage inhibition of haemolysis was calculated as per Equation (1).

\subsubsection{Heat Induced Albumin Denaturation}

The inhibition potential of various solvent fractions of CT to heat induced albumin denaturation was carried out as per Mizushima et al., [39] with modification and compared to the known anti-inflammatory drug ibuprofen. To $2 \mathrm{ml}$ of various concentrations [100 - $1600 \mu \mathrm{g} / \mathrm{ml}$ ] of solvent extract/ibuprofen dissolved in DMSO, $0.2 \mathrm{ml}$ of $1 \%$ bovine serum albumin [BSA] in water and $2.8 \mathrm{ml}$ of phosphate buffer saline [PH 7.4] were added. In the control, $2 \mathrm{ml}$ of DMSO was taken instead of extract/ibuprofen, whereas in the blank BSA and extract/ibuprofen were replaced by water and DMSO respectively. These were then incubated at $37^{\circ} \mathrm{C}$ for 30 minutes followed by 5 minutes incubation at $70^{\circ} \mathrm{C}$. The absorbance of the turbid solution was recorded at $660 \mathrm{~nm}$ against the blank and percentage inhibition of protein denaturation was calculated as per Equation (1).

\section{Statistical Analysis}

Data generated from quantitative assays were expressed as mean values with standard deviation. The percentage yield of the different solvent extract of CT was determined as $\%$ yield $=\mathrm{W} 1 / \mathrm{W} 2 \times 100$, where $\mathrm{W} 1$ is the weight of dry ex- 
tract after evaporation of the solvent used for extraction and W2 is the weight of the CT powder initially taken. The TPC, TTC and TFC were calculated from MS Excel software and using the formula: $\mathrm{T}=\mathrm{C} \times \mathrm{V} / \mathrm{W}$, where; $\mathrm{T}$ : total content [Phenol/flavonoid/tannin compounds] in $\mathrm{mg} / \mathrm{g}$ of solvent extract calculated as gallic acid/quercetin/tannic acid equivalents, C: the concentration of the Phenol/flavonoid/tannin established from the calibration curve of gallic ac$\mathrm{id} /$ quercetin/tannic acid as described in method section in $\mathrm{mg} / \mathrm{ml}$, V: the volume of extract in $\mathrm{ml}$, W: weight of solvent extract in g. Comparison among mean values was made by unpaired t-test and a $\mathrm{P}$ value of $<0.05$ was considered as significant. Linear regression analysis was used to calculate $\mathrm{EC}_{50}$ values using the formula $\mathrm{Y}=\mathrm{MX}+\mathrm{C}$, where $\mathrm{Y}$ represents $50 \%$ inhibition, $\mathrm{M}$ represents the co-efficient [slope], $\mathrm{X}$ represents the $\mathrm{EC}_{50}$ and $\mathrm{C}$ is the intercept. All analyses were run in triplicates unless otherwise stated.

\section{Results}

Petroleum benzene [PB: $13.88 \mathrm{gm}$ ] and aqueous fractions [Aq: $3.6 \mathrm{gm}$ ] resulted in the highest amount of total extractable compounds followed by ethyl acetate [EA: $1.8 \mathrm{gm}$ ] and methanol [1.46 gm], whereas the extraction yield with chloroform [CH: $0.25 \mathrm{gm}]$ was significantly less $[\mathrm{P}<0.01]$ as compared to all other solvent fractions. The qualitative analysis of phyto-chemicals in different solvent extracts of coconut testa is shown in Table 1. The results showed that alkaloids were present in all solvents extracts except for methanol. The PB and EA extracts contained glycosides, fats and oil. Saponin was found in $\mathrm{PB}$ and $\mathrm{CH}$ fractions, whereas sterol was observed only in PB fraction. Interestingly, polyphenolic compounds [phenols, flavonoids, tannin, lignin, coumarin and quinones] were exclusively obtained in methanolic fractions. Lignin was also present in $\mathrm{CH}$ and EA fractions whereas resin was obtained only in EA fraction.

\subsection{Total Phenolics, Flavonoids and Tannin Contents}

Estimation of phenolics, flavonoids and tannin contents in various solvent extracts of coconut testa showed their presence only in methanolic fractions, both in qualitative and quantitative tests [negative values were obtained]. The total phenolics content in methanolic fractions was found to be [822.60 \pm 16.36$] \mathrm{mg}$ gallic acid equivalent/g, flavonoid contents to be [103.30 \pm 9.78$] \mathrm{mg}$ quercetin equivalent/g and tannin to be [663.50 \pm 19.26$] \mathrm{mg}$ tannic acid equivalent/g.

\subsection{In Vitro Antioxidant Activity}

The antioxidant activities of various solvent extracts of coconut testa were investigated by in vitro scavenging ability to free radicals such as DPPH and ABTS, reductions of molybdenum from Mo [VI] to Mo [V], chelating of $\mathrm{Fe}^{2+}$, reductions of cupric ion [CUPRAC assay] and ferric ions [reducing power assay] using standard oxidants as positive control. The $\mathrm{EC}_{50}$ values were determined for $\mathrm{DPPH}, \mathrm{ABTS}$, Phosphomolybdenum and metal chelating assays where low $\mathrm{EC}_{50}$ represents 
Table 1. Qualitative screening of phytochemicals in different solvent fractions of CT

\begin{tabular}{|c|c|c|c|c|c|c|}
\hline \multicolumn{2}{|c|}{ PHYTOCHEMICAL TEST } & \multirow{2}{*}{$\begin{array}{c}\text { PB } \\
+\end{array}$} & \multirow{2}{*}{$\frac{\mathrm{CH}}{+}$} & \multirow{2}{*}{$\begin{array}{l}\text { EA } \\
+++\end{array}$} & \multirow{2}{*}{$\begin{array}{c}\text { Methanol } \\
-\end{array}$} & \multirow{2}{*}{$\begin{array}{c}\text { Aqueous } \\
-\end{array}$} \\
\hline ALKALOIDS & Dragendorff's Test & & & & & \\
\hline & Mayer's Test & + & ++ & + & - & + \\
\hline & Hager's Test & ++ & ++ & + & - & + \\
\hline & Tanic acid Test & - & - & ++ & - & ++ \\
\hline & $\mathrm{FeCl}_{3}$ Test & + & + & ++ & - & ++ \\
\hline & Wagner's Test & - & + & - & - & - \\
\hline \multirow[t]{4}{*}{ GLYCOSIDES } & Kellar Kiliani Test & + & - & - & - & - \\
\hline & Molisch's test & + & - & ++ & - & - \\
\hline & Conc. $\mathrm{H}_{2} \mathrm{SO}_{4}$ Test & ++ & - & - & + & - \\
\hline & Legal's test & ++ & + & ++ & - & - \\
\hline \multirow[t]{5}{*}{ TANNINS } & Gelatin test & - & - & - & +++ & - \\
\hline & Pot.dichromate test & - & - & - & ++ & - \\
\hline & Alkaline Reagent test & - & - & - & ++ & - \\
\hline & $\mathrm{Fecl}_{3}$ test & - & - & - & +++ & - \\
\hline & Lead acetate test & - & - & - & ++ & - \\
\hline \multirow[t]{3}{*}{ FLAVONOID } & $\mathrm{FeCl}_{3}$ Test & - & - & - & +++ & - \\
\hline & Alkaline Reagent test & - & - & - & ++ & - \\
\hline & Shinoda's Test & - & - & - & + & - \\
\hline \multirow[t]{2}{*}{ STEROLS } & Salkowski test & + & - & - & - & - \\
\hline & Liberman burchard test & + & - & - & - & - \\
\hline \multirow[t]{2}{*}{ FATS \& OILS } & Stain test (using Filter paper) & + & - & - & - & + \\
\hline & Saponification test & + & - & + & - & - \\
\hline \multirow[t]{2}{*}{ PHENOLS } & $\mathrm{FeCl}_{3}$ Test & - & - & - & +++ & - \\
\hline & Elagic Acid test & - & - & - & ++ & - \\
\hline \multirow[t]{2}{*}{ LIGNINS } & Furfuraldehyde test & - & + & + & + & - \\
\hline & Labat test & - & - & - & + & - \\
\hline QUINONES & Alcoholic $\mathrm{KOH}$ Test & - & - & - & + & - \\
\hline SAPONIN & Foam Test & +++ & ++ & - & - & - \\
\hline Cumarin & Cumarin test & + & - & - & + & - \\
\hline Resin & $\mathrm{CuSO}_{4}$ test & - & - & ++ & - & - \\
\hline
\end{tabular}

Phytochemicals screening was carried out according to the methods provided in Sheel et al. [24], Nanna et al. [25], Mishra et al. [26], and Sharma et al. [27]. "+" indicates presence and "-" indicates absence. The increase in + sign indicates the intensity.

stronger antioxidant activity (Table 2). In CUPRAC and reducing power assays, the anti-oxidant activities increased with absorption value at respective wavelengths.

\subsubsection{DPPH" Scavenging Activity}

The results showed that chloroform $\left[\mathrm{EC}_{50}=2.37\right]$ and methanolic extracts $\left[\mathrm{EC}_{50}\right.$ 
$=2.63 \mathrm{~J}$ of the testa had the similar ability to scavenge $\mathrm{DPPH}^{*}$ free radicals, which were higher than the known anti-oxidants $\mathrm{BHT}\left[\mathrm{EC}_{50}=3.02\right]$ and tannic acid $\left[\mathrm{EC}_{50}=3.74\right]$. While $78 \%$ of inhibition was noted for methanolic extracts, $80 \%$ inhibition was observed by chloroform extracts at a concentration of $12.5 \mu \mathrm{g} / \mathrm{ml}$.

\subsubsection{ABTS+ Scavenging Activity}

In all the extracts tested, only methanolic extracts had the highest anti-oxidant activity with an $\mathrm{EC}_{50}$ value of 2.57 , which is lowest among all including the known anti-oxidants gallic acid $\left[\mathrm{EC}_{50}=4.4\right]$, quercetin $\left[\mathrm{EC}_{50}=5.67\right]$, tannic acid $\left[\mathrm{EC}_{50}=5.15\right], \mathrm{BHT}\left[\mathrm{EC}_{50}=13.12\right]$ and ascorbic acid $\left[\mathrm{EC}_{50}=23.14\right]$. The ethyl acetate extracts also showed potent anti-oxidant activity with an $\mathrm{EC}_{50}=8.67$. At a concentration of $12.5 \mu \mathrm{g} / \mathrm{ml}$, while methanolic extract exhibited an inhibition of $83.57 \%$, gallic acid inhibited $74.28 \%$, quercetin and tannic acid inhibited $72.14 \%$ and $72.85 \%$ respectively, ascorbic acid $62.85 \%$ and BHT $67.85 \%$.

\subsubsection{Phosphomolybdenum Assay}

In phosphomolybdenum assay, the reductions of Mo [VI] to Mo [V] by various solvent fractions of coconut testa were calculated as ascorbic acid equivalent. The results showed the presence of effective antioxidants activity in petroleum benzene $\left[\mathrm{EC}_{50}=112.73 \mu \mathrm{g} / \mathrm{ml}\right]$ and methanolic fractions $\left[\mathrm{EC}_{50}=149.16 \mu \mathrm{g} / \mathrm{ml}\right]$ of testa which corresponds to the $\mathrm{EC}_{50}$ value of $51.79 \mu \mathrm{g} / \mathrm{ml}$ of reference chemicals, ascorbic acid (Table 2). The ethyl acetate fraction had the least activity.

\subsubsection{Metal Chelating Assay}

Assessment of various solvent extracts of coconut testa for their chelating ability of ferrous ions revealed that only methanolic and aqueous fractions had the power

Table 2. Radical scavenging activity of different solvent extracts of coconut testa.

\begin{tabular}{|c|c|c|c|c|}
\hline \multirow{2}{*}{ Plant extracts/control } & \multicolumn{4}{|c|}{$\mathrm{EC}_{50}$ value } \\
\hline & ABTS & DPPH & PM Assay & Metal chelating* \\
\hline Petroleum benzene & 94.86 & 26.37 & 112.73 & ----------- \\
\hline Chloroform & 37.60 & 2.36 & 403.01 & --------- \\
\hline Ethyl Acetate & 8.67 & 29.83 & 610.72 & --------- \\
\hline Methanol & 2.57 & 2.63 & 149.16 & 4.17 \\
\hline Aqueous & 65.66 & 29.56 & 430.36 & 25.52 \\
\hline Ascorbic acid & 23.14 & 1.66 & 51.79 & ---------- \\
\hline BHT & 13.12 & 3.02 & ---------- & ---------- \\
\hline Gallic acid & 4.40 & 1.96 & 1026.24 & - --------- \\
\hline Quercetin & 5.67 & 0.073 & ---------- & - \\
\hline EDTA & ------.--. & -1-- & ---------- & 0.16 \\
\hline Tannic acid & 5.15 & 3.74 & 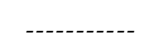 & 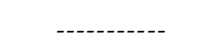 \\
\hline
\end{tabular}

¥: ascorbic acid equivalent values for different concentration of solvent extracts were analyzed for $\mathrm{IC}_{50}$ estimation. * : metal chelating activity were exhibited by methanolic and aqueous extracts of coconut testa (values are expressed in $\mathrm{mg} / \mathrm{ml}$ ), all other values are expressed in $\mu \mathrm{g} / \mathrm{ml}$. 
to reduce iron ion $\mathrm{Fe}[\mathrm{III}]$ into $\mathrm{Fe}[\mathrm{II}]$ in a dose-dependent manner. The $\mathrm{EC}_{50}$ for the chelation of iron ion by methanolic fractions was found to be $4.17 \mathrm{mg} / \mathrm{ml}$ and for aqueous fraction was $25.52 \mathrm{mg} / \mathrm{ml}$ as against the EDTA which had an $\mathrm{EC}_{50}$ of $0.162 \mathrm{mg} / \mathrm{ml}$.

\subsubsection{Reducing Power and CUPRAC Assays}

Figure 1(a) and Figure 1(b) show the reducing ability of various solvents fractions of coconut testa for ferric ion and cupric ion in reducing power assay and CUPRAC assay respectively using quercetin and ascorbic acid as control. The dose response curve [62.5 - $1000 \mu \mathrm{g} / \mathrm{ml}$ ] of various solvent extracts including the control showed the increased reduction of ions with an increase in the concentration of each extract and control samples. However, in both the assays the methanolic fraction showed the highest reducing ability compared to all other solvent extracts. In reducing power assay, although the methanolic fraction had comparatively low anti-oxidant activity than quercetion and ascorbic acid within the concentration
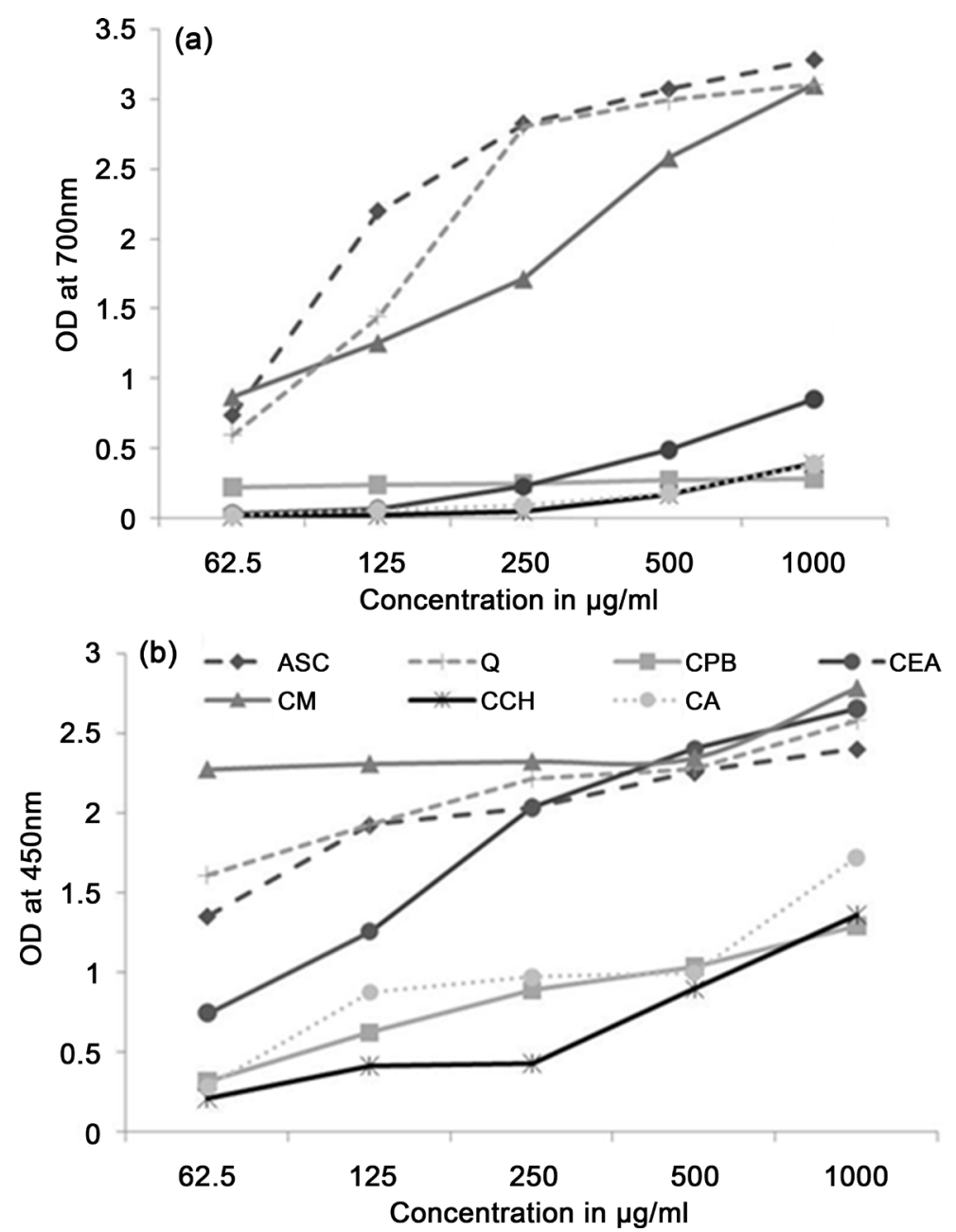

ASC: Ascorbic acid, Q: Quercetin, CPB: Petroleum benzene, CEA: Ethyl acetate, CM: Methanol, $\mathrm{CCH}$ : Chloroform, CA: Aqueous, OD: Optical density.

Figure 1. Reducing ability of coconut testa in reducing power assay (a) and CUPRAC assay (b). 
range of $125-500 \mu \mathrm{g} / \mathrm{ml}$, this activity was comparable at $1000 \mu \mathrm{g} / \mathrm{ml}$. However, in CUPRAC assay the methanolic fraction exhibited high-reduction activity compared to the control, quercetion and ascorbic acid at all range of studied concentration. Besides, the ethyl acetate fraction also showed high anti-oxidant activity than quercetion and ascorbic acid at a concentration beyond $500 \mu \mathrm{g} / \mathrm{ml}$.

\subsection{Anti-Microbial Assay}

The screening results for antimicrobial activity of different solvent extracts against two bacterial strains; one gram positive such as Staphylococcus aureus, and one gram negative such as Escherichia coli, and one fungal strain Candida albicans are presented in Table 3. The results indicated that petroleum benzene, chloroform and methanolic fractions of coconut testa had antibacterial and antifungal activity against all tested pathogens with a maximum zone of inhibition obtained for the methanolic fraction. However, while aqueous extract showed antibacterial activity against $\mathrm{S}$. aureus only with a maximum zone of inhibition [17.33 mm] which is highest compared to all other solvent extracts, ethyl acetate fraction did not exhibit any antimicrobial activity against the test pathogens at a concentration of $10 \mathrm{mg} / \mathrm{ml}$.

\subsection{Anti-Inflammatory Assay}

Investigation for anti-inflammatory activity of different solvent fractions of CT by membrane stabilization of heat and hypotonic solution induced human red blood cell haemolysis and inhibition of heat induced albumin denaturation assay revealed that aqueous fraction had the highest anti-inflammatory activity comparable to that of the known anti-inflammatory drug ibuprofen followed by the $\mathrm{CH}$ fraction and methanolic fraction (Table 4). The PB and EA fractions had the least activity. The heat induced HRBC assay for the EA extract could not be carried out due to lack of the extract as the percentage yield of EA fraction was very very less.

Table 3. Antimicrobial activity of different solvent fractions of CT.

\begin{tabular}{cccc}
\hline CT extract & S. aureus & E. coli & C.albicans \\
\hline PB & $10.00 \pm 1.414$ & $15.00 \pm 2.00$ & $20.00 \pm 1.00$ \\
CH & $11.33 \pm 0.57$ & $16.33 \pm 3.21$ & $22.33 \pm 0.577$ \\
Methanol & $12.33 \pm 0.577$ & $17.66 \pm 1.15$ & $24.66 \pm 0.577$ \\
EA & $\mathrm{NZ}$ & $\mathrm{NZ}$ & $\mathrm{NZ}$ \\
Aqueous & $17.33 \pm 2.08$ & $\mathrm{NZ}$ & $\mathrm{NZ}$ \\
Azithromycin & $22.33 \pm 1.52$ & $23.66 \pm 0.57$ & ------ \\
Fluconazole & ---- & $---{ }^{2}$ & $22.66 \pm 1.52$ \\
\hline
\end{tabular}

PB: Petrolium benzene extract, $\mathrm{CH}$ : Chloroform extract, EA: Ethyl acetate extract. The zones of inhibition were measured in millimeter. Values are obtained in triplicates and expressed in mean \pm standard deviation. NZ: no zone. 
Table 4. Anti-inflammatory activity of different solvent fractions of CT.

\begin{tabular}{cccc}
\hline \multirow{3}{*}{ Samples } & \multicolumn{3}{c}{$\mathrm{EC}_{50}(\mu \mathrm{g} / \mathrm{ml})$} \\
\cline { 2 - 4 } & Hypotonic HRBC & Heat induced HRBC & BSA \\
\hline PB & $393.63 \pm 31.29$ & $1003.60 \pm 22.10$ & $1729.12 \pm 57.20$ \\
CH & $71.59 \pm 11.27$ & $105.96 \pm 19.86$ & $71.25 \pm 12.39$ \\
EA & $2132.19 \pm 349.20$ & $1978.00 \pm 457.30$ & $1709.12 \pm 71.20$ \\
Methanol & $214.58 \pm 21.16$ & $129.07 \pm 8.91$ & $226.05 \pm 19.26$ \\
Aqueous & $53.20 \pm 6.12$ & $20.81 \pm 6.70$ & $50.20 \pm 7.90$ \\
IP & $40.30 \pm 4.60$ & $71.59 \pm 9.86$ & $24.26 \pm 5.90$ \\
\hline
\end{tabular}

PB: Petrolium benzene extract, CH: Chloroform extract, EA: Ethyl acetate extract and IP: ibuprofen. Values are expressed in mean \pm SD after the results were obtained in triplicates. For heat induced haemolysis assay, EA extract was not available at the time of experiment.

\section{Discussion}

The present investigation shows that CT contains a diverse group of phytochemicals such as alkaloids, glycosides, saponin, sterol, phenols, flavonids, tannin, quinines, lignin, resin, coumarin, fats and oil. However, previous phytochemical screening studies have reported the presence of phenolic compounds [phenols, flavonids, tannin and triterpenes], saponin and glycosides in CT extract with 70\% ethanol [20] [40]. While saponin was found in PB and CH extract in the present study, it was reported in the ethanolic fractions along with carbohydrates and proteins [20]. We documented for the presence of more number of phytochemicals because of the use of different solvents of varying polarity in the sequential extraction process which has extracted all of the solvent soluble compounds. Otherwise, these phytochemicals would have gone unextracted with the use of a single solvent or few solvent systems of similar polarity as observed previously. CT is anticipated as a potential source of polyphenolic compounds as evidenced by a significant increase in the total phenol content of coconut milk obtained from the grating with testa [41]. Besides, increased phenolic contents in coconut oil extracted from the kernel with testa had been observed compared to white coconut kernel alone [23] and the oil extracted from coconut testa was rich in phenolic compounds [7]. In a recent study, it has been observed that the extractability of phenolics and flavonoid compounds from CT were found to be affected largely by the polarity and acidification of the solvents used in extraction and that the maximum yield of total phenolic compounds [167 mg GAE/g] was obtained with $80 \%$ acidified acetone [9]. Several other studies also evidence for aqueous acetone as the efficient solvent system in extracting phenolic compounds in different plant species [42] [43] [44] [45]. So far, the maximum extractability of total phenolic content from CT were obtained with $80 \%$ acidified acetone [9] followed by $44.61 \mathrm{mg} \mathrm{GAE} / \mathrm{g}$ with $70 \%$ ethanol [8], 0.78 to $2.41 \mathrm{mg}$ GAE/g with aqueous extract of fermented coconut testa [14], $1.9 \mathrm{mg} \mathrm{GAE} / 100 \mathrm{~g}$ with $80 \%$ methanol [7] and $1.3 \mathrm{~g} / 100 \mathrm{~g}$ with ethanol as a solvents [20]. However, 
in the present study we documented the total phenolic content of CT to be as high as $822.6 \mathrm{mg}$ GAE/g in the methanolic fraction. Previous sequential extraction studies with soxhlet also reveal high phenolic content in the methanolic fraction from various parts of Moringa oleifera [46] and of Caesalpinia digyna root [47]. The fact that polyphenolic compounds in plants are mostly found in conjugated forms with glycosides, proteins and sugars which are soluble in the specific solvent system [16] [48] [49]. The present finding of enhanced phenolic content in the methanolic fraction during sequential extraction with different solvents of varying polarity could be explained by the sequential elimination of solvent soluble non-polar compounds and interfering unwanted non-phenolic substances such as wax, fats, terpenes, etc. This is partially evidenced by the removal of almost all glycosides, sterol, saponin, resin, fats and oil before extraction with methanol (Table 1). The lack of phenolic compounds in non-polar organic solvents indicates the absence of more complex forms of polyphenolic compounds in the CT. Further, the finding of polyphenols compound exclusively in methanolic fraction can be attributed to the polar nature of the phenolic compounds of CT, although methanol can also dissolve non-polar compounds for being amphiphilic in nature. However, the absence of phenolic compounds in aqueous fraction as well suggests that very polar phenolic acids [such as benzoic, cinnamic acids] could be present in negligible or undetected amounts or maybe absent completely. Our study represent that the sequential soxhlet extraction process adopted here could be a potential tool of isolating maximum phenolic compounds at least from CT and has an added advantage of separating phytochemicals in different solvent fractions which could be utilized in purification post extraction.

In order to accurately measure the effectiveness of antioxidants potential of various solvent extracts of CT, we evaluated the anti-oxidant activities through different methods of multiple reaction characteristics viz. DPPH and ABTS radical scavenging activity, Phosphomolybdate, CUPRAC and ferric reducing power assays-based on the single electron transfer, and metal chelating assay based on co-ordinate complex formation with the metal ions inhibiting the transfer of electrons [50] [51]. The results of various antioxidant assays are given in Table 2. To date, this is the first study to report and compare the anti-oxidant activities of different solvent fractions of coconut testa. The results showed that methanolic fraction of the CT had invariably the highest anti-oxidant activity than all other solvent fractions in almost all assay methods except in phosphomolybdate assay where $\mathrm{PB}$ fraction showed the highest activity $\left[\mathrm{EC}_{50}=112.73\right.$ ] followed by methanolic fraction $\left[\mathrm{EC}_{50}=149.16\right]$. In some cases, the methanolic fraction revealed anti-oxidant activity similar to or even greater than the known anti-oxidants (Table 2). This is not surprising, as the methanolic fraction exclusively contained the polyphenol compounds and that total phenolic content and anti-oxidant activities of various plant extracts including the CT were reported to be in direct positive co-relationship [46] [52] [53]. However, more or less the 
constant presentation of highest anti-oxidant activities in multiple assay methods, which involve different reaction mechanism, $\mathrm{P}^{\mathrm{H}}$ conditions and vary according to compound type (hydrophilic and lipophilic) [54] [55] by methanolic fraction indicates it to be a source of multiple phenolics and flavonoids of potent anti-oxidant activities. This is further supported by a recent identification of about 28 polyphenolics comprising of 16 phenolic acids and 12 flavonoids from the CT [9]. Considering the methanolic fraction of the present study as the exclusive source of polyphenolic compounds of CT, we expect for the presence of even more number of polyphenolics in this fraction which is yet to be characterized. Interestingly, the exhibition of potent anti-oxidant activities by the $\mathrm{CH}$ fraction $\left[\mathrm{EC}_{50}=2.369\right.$ in $\mathrm{DPPH}$ assay] and EA fraction $\left[\mathrm{EC}_{50}=8.67\right.$ in ABTS assay] along with PE fraction suggest that bioactivity of CT in terms of anti-oxidant activities can also be contributed by non-polyphenolic compounds and are not limited to polyphenolic compounds only. Similar, high anti-oxidant activities by non-phenolic compounds also have been reported by previous studies on pomegranate [56] and Buddleja asiatica [57]. Our study brings attention to different solvent fractions of CT containing phenolic and non-phenolic compounds to be a source of natural antioxidant and ensure that the CT can be better exploited for the medicinal benefit of the human.

It is established that lysosomal secretion of various enzymes and denaturation of proteins [where the later is usually the basis of the autoimmune disorder including rheumatoid arthritis] are well documented cause of inflammation [58] [39]. Therefore, stabilizing the lysosomal membrane or preventing the release of lysosomal enzymes along with inhibition of protein denaturation have been considered as a measure of anti-inflammatory activity for plant extracts or drugs. Owing to the structural analogy of human red blood cell [HRBC] with lysosomal membrane [59] [60] [61], the in vitro anti-inflammatory activity of various solvent extracts of CT was determined by percentage inhibition of hypotonicity or heat induced HRBC membrane lysis. Besides, the ability of different solvent extracts to inhibit heat induced albumin denaturation was studied. Our results showed that the aqueous fraction had the comparable anti-inflammatory activity with the known drug ibuprofen followed by the $\mathrm{CH}$ fraction and that both of these fractions derived from CT do not contain any polyphenolic compounds. We observed some anti-inflammatory activity of methanolic fraction containing polyphenolic compounds. However, these activities were less than that of aqueous and $\mathrm{CH}$ fraction. Although anti-inflammatory activities are usually attributed to the polyphenolic compounds present in the plant extracts [4] [62] [63] [64], there are limited studies [65] [66] including ours which witness non-polyphenolics as potent anti-inflammatory compounds. In the absence of any mechanistic study, the resistance to cell lysis of these CT derived compounds could be due to alteration of the surface charges of the cells preventing or promoting physical interaction with different agents involved in the haemolysis of red blood cells [67], expansion of membrane or shrinkage of the cell or by 
interaction with membrane proteins thereby increasing the surface area/volume ratio which needs to be investigated. Moreover, alteration of ion influx into erythrocytes cannot be ruled out as a change in volume and deformability of erythrocytes has been shown to be correlated with intracellular calcium ion content [68] [69].

To the best of our knowledge, no previous report exists evaluating the antimicrobial activity of CT. Further, antimicrobial activity of plant extracts have been shown to vary with the solvent used for extract preparation [70] [71] [72] and bacterial [gram positive or gram negative] and fungal pathogen tested. Therefore, we assessed the antimicrobial activity of various solvent fractions of CT using two bacterial [S. aureus and E. coli] and one fungal pathogen [C. albicans]. The results indicated that aqueous extract did not show any activity against the gram negative E. coli and fungal pathogen, though it had the highest antibacterial activity compared to all other solvent fractions against the gram positive $S$. aureus. Earlier studies also suggest gram-negative bacteria to be generally more resistant to various drugs and antibiotics than gram-positive bacteria [73] and these differences in susceptibility by the aqueous fraction in the present study could be explained by the differences in cell wall composition or drug resistant genes on plasmids they inherited with. However, fractions of coconut testa obtained with organic solvents [PB, $\mathrm{CH}$ and methanol] had antibacterial and antifungal activity against all tested pathogens with the maximum zone of inhibition obtained for methanolic fraction. In most of the cases, organic extracts have been shown to exhibit greater antimicrobial activity compared to aqueous extract [74], although this is not universal. This suggests that relatively hydrophobic nature of the compounds in CT had the ability to kill both gram positive and gram negative bacteria along with fungal pathogens.

\section{Conclusion}

Overall, our study reveals that CT is a rich source of various polyphenolic and non-phenolic natural antioxidants, anti-inflammatory and antimicrobial compounds. Although the number of active components and their chemical and physical nature in each extract are unclear, the findings of the study are promising and can form the basis to exploit the CT for therapeutic benefits. Further research is warranted to characterize the individual component of the active principle.

\section{Acknowledgements}

We acknowledge the financial support of Department of Science and Technology, Govt. of Odisha, India [27552800232014/20(2802)] towards performing the laboratory work and for providing fellowship to Ms Shaktirekha Roy, Research fellow. We appreciate and thank Department of Science and Technology, Govt. of India for providing INSPIRE fellowship to Sashibhusan Ojha. The authors also thankfully acknowledge the Vice Chancellor, North Orissa University (NOU), and to the Head, Department of Biotechnology, NOU, for providing necessary 
administrative and laboratory facilities for the study.

\section{Conflicts of Interest}

The authors declare no conflicts of interest regarding the publication of this paper.

\section{References}

[1] Manivannan, A., Bhardwaj, R., Padmanabhan, S., Suneja, P., Hebbar, K.B. and Kanade, S.R. (2018) Biochemical and Nutritional Characterization of Coconut (Cocos nucifera L.) Haustorium. Food Chemistry, 238, 153-159.

https://doi.org/10.1016/j.foodchem.2016.10.127

[2] DebMandal, M. and Mandal, S. (2011) Coconut (Cocos nucifera L.: Arecaceae): In Health Promotion and Disease Prevention. Asian Pacific Journal of Tropical Medicine, 4, 241-247. https://doi.org/10.1016/S1995-7645(11)60078-3

[3] Yong, J.W.H., Ge, L.-Y., Ng, Y.F. and Tan, S.N. (2009) The Chemical Composition and Biological Properties of Coconut (Cocos nucifera L.) Molecules, 14, 5144-5164. https://doi.org/10.3390/molecules14125144

[4] Zhang, L., Ravipati, A.S., Koyyalamudi, S.R., Jeong, S.C., Reddy, N., Smith, P.T., Bartlett, J., Shanmugam, K., Munch, G. and Wu, M.-J. (2011) Antioxidant and Anti-Inflammatory Activities of Selected Medicinal Plants Containing Phenolic and Flavonoid Compounds. Journal of Agricultural and Food Chemistry, 59, 12361-12367. https://doi.org/10.1021/jf203146e

[5] Lathika, M. and Kumar, C.E.A. (2009) Indian Stakes in the Global Coconut Scenario by the Turn of the Century: An Empirical Investigation. South Asia Economic Journal, 10, 209-221. https://doi.org/10.1177/139156140901000109

[6] Marikkar, J.M.N. and Madhrapperuma, W.S. (2012) Chapter 9. Coconut. In: Siddiq, M., Ed., Tropical and Subtropical Fruits: Postharvest Physiology, Processing and Packaging, John-Wiley Publishing Co., Ames, Iowa, USA, 159-177. https://doi.org/10.1002/9781118324097.ch9

[7] Appaiah, P., Sunil, L., Prasanth Kumar, P.K. and Gopala Krishna, A.G. (2014) Composition of Coconut Testa, Coconut Kernel and Its Oil. Journal of the American Oil Chemists' Society, 91, 917-924. https://doi.org/10.1007/s11746-014-2447-9

[8] Adekola, K.A., Salleh, A.B., Zaidan, U.H., Azlan, A., Chiavaro, E., Paciulli, M. and Marikkar, J.M.N. (2017) Total Phenolic Content, Antioxidative and Antidiabetic Properties of Coconut (Cocos nucifera L.) Testa and Selected Bean Seed Coats. Italian Journal of Food Science, 29, 741-753.

[9] Arivalagan, M., Roy, T.K., Yasmeen, A.M., Pavithra, K.C., Jwala, P.N., Shivasankara, K.S., Manikantan, M.R., Hebbar, K.B. and Kanade, S.R. (2018) Extraction of Phenolic Compounds with Antioxidant Potential from Coconut (Cocos nucifera L.) Testa and Identification of Phenolic Acids and Flavonoids Using UPLC Coupled with TQD-MS/MS. LWT-Food Science and Technology, 92, 116-126. https://doi.org/10.1016/j.lwt.2018.02.024

[10] Pandey, K.B. and Rizvi, S.I. (2009) Plant Polyphenols as Dietary Antioxidants in Human Health and Disease. Oxidative Medicine and Cellular Longevity, 2, 270-278. https://doi.org/10.4161/oxim.2.5.9498

[11] Manach, C., Scalbert, A., Morand, C., Rémésy, C. and Jiménez, L. (2004) Polyphenols: Food Sources and Bioavailability. The American Journal of Clinical Nutrition, 79, 727-747. https://doi.org/10.1093/ajcn/79.5.727 
[12] Everitt, A.V., Hilmer, S.N., Brand-Miller, J.C., Jamieson, H.A., Truswell, A.S., Sharma, A.P., Mason, R.S., Morris, B.J. and Le Couteur, D.G. (2006) Dietary Approaches That Delay Age-Related Diseases. Clinical Interventions in Aging, 1, 11-31.

[13] Działo, M., Mierziak, J., Korzun, U., Preisner, M., Szopa, J. and Kulma, A. (2016) The Potential of Plant Phenolics in Prevention and Therapy of Skin Disorders. International Journal of Molecular Sciences, 17, 160. https://doi.org/10.3390/ijms17020160

[14] Razak, D.L.A., Jamaluddin, A., YuhaslizaAbd. N., Rashid, Sharifudin, S.A. and Long, K. (2016) Comparative Study of Antioxidant Activities, Cosmeceutical Properties and Phenolic Acids Composition of Fermented Rice Bran and Coconut Testa. Jurnal Teknologi (Sciences \& Engineering), 78, 11-12. https://doi.org/10.11113/jt.v78.9940

[15] Swaroop, C., Jose, T.K. and Ramesh, A. (2016) Property Testing of Biodiesel Derived from Coconut Testa Oil and Its Property Comparison with Standard Values. International journal of Advances in Production and Mechanical Engineering, 2, 37-41.

[16] Khoddami, A., Meredith, A.W. and Thomas, H.R. (2013) Techniques for Analysis of Plant Phenolic Compounds. Molecules, 18, 2328-2375. https://doi.org/10.3390/molecules 18022328

[17] Sun, T. and Ho, C.-T. (2005) Antioxidant Activities of Buckwheat Extracts. Food Chemistry, 90, 743-749. https://doi.org/10.1016/j.foodchem.2004.04.035

[18] Turkmen, N., Sari, F. and Velioglu, Y.S. (2006) Effects of Extraction Solvents on Concentration and Antioxidant Activity of Black and black Mate Tea Polyphenols Determined by Ferrous Tartrate and Folin-Ciocalteu Methods. Food Chemistry, 99, 835-841. https://doi.org/10.1016/j.foodchem.2005.08.034

[19] Hayouni, A., Abedrabba, M., Bouix, M. and Hamdi, M. (2007) The Effects of Solvents and Extraction Method on the Phenolic Contents and Biological Activities in Vitro of Tunisian Quercus coccifera L. and Juniperus phoenicea L. Fruit Extracts. Food Chemistry, 105, 1126-1134. https://doi.org/10.1016/j.foodchem.2007.02.010

[20] Appaiah, P., Sunil, L., Gopala Krishna, A.G. and Suresh Kumar, G. (2016) Phytochemicals and Antioxidant Activity of Testa Extracts of Commercial Wet and Dry Coconuts and Cakes. International Research Journal of Pharmacy, 7, 9-13. https://doi.org/10.7897/2230-8407.079106

[21] Zhao, X.-L., Chen, W.-J., Zhao, S.-L. and Tang, M.-M. (2012) Antioxidative Activity of the Extractives from Coconut Testa Oil. Chinese Journal of Tropical Crops, 33, 162-165.

[22] Sashya, M.M.M., Meedeniya, D. and Coorey, R.V. (2012) Quality Assessment of Commercially Available Coconut Oils in Sri Lanka Using Refractometry. Proceedings of the Technical Sessions, 28, 37-44.

[23] Seneviratne, K.N., HapuarachchI, C.D. and Ekanayake, S. (2009) Comparison of the Phenolic-Dependent Antioxidative Properties of Coconut Oil Extracted under Cold and Hot Conditions. Food Chemistry, 114, 1444-1449. https://doi.org/10.1016/j.foodchem.2008.11.038

[24] Sheel, R., Nisha, K. and Kumar, J. (2014) Preliminary Phytochemical Screening of Methanolic Extract of Clerodendron infortunatum. IOSR-Journal of Applied Chemistry, 7, 10-13. https://doi.org/10.9790/5736-07121013

[25] Nanna, R.S., Marka, R., Talari, S., Penchala, S. and Rudroju, S. (2013) Preliminary Phytochemical Analysis of Leaf, Stem, Root and Seed Extracts of Arachis hypogaea L. International Journal of Pharmaceutical Sciences Review and Research, 20, 134-139. 
[26] Saklani, S., Mishra, A.P., Sati, B. and Sati, H. (2012) Pharmacognostic, Phytochemical and Antimicrobial Screening of Aphanamixis polystachya, An Endangered Medicinal Tree. International Journal of Pharmacy and Pharmaceutical Sciences, 4, 235-240.

[27] Sharma, V., Agarwal, A., Chaudhary, U. and Singh, M. (2013) Phytochemical Investigation of Various Extracts of Leaves and Stems of Achyranthes aspera L. International Journal of Pharmacy and Pharmaceutical Sciences, 5, 317-320.

[28] Ebrahimzadeh, M.A., Pourmorad, F. and Bekhradnia, A.R. (2008) Iron Chelating Activity, Phenol and Flavonoid Content of Some Medicinal Plants From Iran. African Journal of Biotechnology, 7, 3188-3192.

[29] Islam T., Hasan, M.R., Roy, A., Islam, M.S., Uddin, M.A., Islam, M.A., Neon, M.N. and Rana, M.S. (2015) Screening of In-Vitro Antioxidant, Brine Shrimp Lethality Bioassay and Antimicrobial Activities of Extracts of Bridelia retusa (L.) Spreng. Fruit. International Journal of Pharmacy, 5, 1058-1067.

[30] Makkar, H.P.S., Dawra, R.K. and Singh, B. (1988) Determination of Both Tannin and Protein in a Tannin-Protein Complex. Journal of Agricultural and Food Chemistry, 36, 523-525. https://doi.org/10.1021/jf00081a600

[31] Chang, S.-T., Wu, J.-H., Wang, S.-Y., Kang, P.-L., Yang, N.-S. and Shyur, L.-F. (2001) Antioxidant Activity of Extracts from Acacia confusa Bark and Heartwood. Journal of Agricultural and Food Chemistry, 49, 3420-3424.

https://doi.org/10.1021/jf0100907

[32] Re, R., Pellegrini, N., Proteggente, A., Pannala, A., Yang, M. and Rice-Evans, C. (1999) Antioxidant Activity Applying an Improved ABTS Radical Cation Decolorization Assay. Free Radical Biology and Medicine, 26, 1231-1237. https://doi.org/10.1016/S0891-5849(98)00315-3

[33] Prieto, P., Pineda, M. and Aguilar, M. (1999) Spectrophotometric Quantitation of Antioxidant Capacity through the Formation of a Phosphomolybdenum Complex: Specific Application to the Determination of Vitamin E. Analytical Biochemistry, 269, 337-341. https://doi.org/10.1006/abio.1999.4019

[34] Dinis, T.C.P., Madeira, V.M.C. and Almeida, L.M. (1994) Action of Phenolic Derivatives (Acetoaaminophen, Salycilate and 5-Aminosalycilate) as Inhibitors of Membrane Lipid Peroxidation and as Peroxyl Radical Scavengers. Archieves of Biochemistry and Biophysics, 315, 161-169. https://doi.org/10.1006/abbi.1994.1485

[35] Oyaizu, M. (1986) [Studies on Products of the Browning Reaction Prepared From Glucose Amine]. The Japanese Journal of Nutrition and Dietetics, 44, 307-315. https://doi.org/10.5264/eiyogakuzashi.44.307

[36] Karaman, S., Tutem, E., Baskan, K.S. and Apak, R. (2010) Comparison of Total Antioxidant Capacity and Phenolic Composition of Some Apple Juices with Combined HPLC-CUPRAC Assay. Food Chemistry, 120, 1201-1209. https://doi.org/10.1016/j.foodchem.2009.11.065

[37] Perez, C., Paul, M. and Bazerque, P. (1990) An Antibiotic Assay by the Agar Well Diffusion Method. Acta Biologiae et Medicinae Experimentalis, 15, 113-115.

[38] Shinde, U.A., Kulkarni, K.R., Phadke, A.S., Nair, A.M., Dikshit, V.J.M. and Saraf, M.N. (1999) Mast Cell Stabilizing and Lipoxygenase Inhibitory Activity of Cedrus deodara (Roxb.) Loud. Wood Oil. Indian Journal of Experimental Biology, 37, 258-261.

[39] Mizushima, Y. and Kobayashi, M. (1968) Interaction of Anti-Inflammatory Drugs with Serum Proteins, Especially with Some Biologically Active Proteins. Journal of Pharmacy and Pharmacology, 20, 169-173. https://doi.org/10.1111/j.2042-7158.1968.tb09718.x 
[40] Geetha, V., Bhavana, K.P., Chetana, R., Gopala Krishna, A.G. and Suresh Kumar, G. (2016) Studies on the Composition and In-Vitro Antioxidant Activities of Concentrates from Coconut Testa and Tender Coconut Water. Journal of Food Processing \& Technology, 7, 588-592.

[41] Lamdande, A.G., Garud, S.R. and Raghavarao K.S.M.S. (2017) Processing Methods for Increasing the Yield, Nutritional Value and Stability of Coconut Milk. International Journal of Nutrition and Food Engineering, 11, 12.

[42] Zhao, H.-F., Dong, J., Lu, J.-J., Chen, J., Li, Y., Shan, L.-J., Lin, Y., Fan, W. and Gu, G.-X. (2006) Effect of Extraction Solvent Mixtures on Antioxidant Activity Evaluation and Their Extraction Capacity and Selectivity for Free Phenolic Compounds in Barley (Hordeum vulgare L.). Journal of Agricultural and Food Chemistry, 54, 7277-7286. https://doi.org/10.1021/jf061087w

[43] Sulaiman, S.F., Sajak, A.A.B., Supriatno, K.L.O. and Seow, E.M. (2011) Effect of Solvents in Extracting Polyphenols and Antioxidants of Selected Raw Vegetables. Journal of Food Composition and Analysis, 24, 506-515.

https://doi.org/10.1016/j.jfca.2011.01.020

[44] Wijekoon, M.M.J.O., Bhat, R. and Karim, A.A. (2011) Effect of Extraction Solvents on the Phenolic Compounds and Antioxidant Activities of Bunga kantan (Etlingera elatior Jack.) Inflorescence. Journal of Food Composition and Analysis, 24, 615-619. https://doi.org/10.1016/j.jfca.2010.09.018

[45] Chavan, U.D. and Amarowicz, R. (2013) Effect of Various Solvent Systems on Extraction of Phenolics, Tannins and Sugars from Beach Pea [Lathyrus maritimus L.]. International Food Research Journal, 20, 1139-1144.

[46] Vyas, S., Kachhwaha, S. and Kothari, S.L. (2015) Comparative Analysis of Phenolic Contents and Total Antioxidant Capacity of Moringa oleifera Lam. Pharmacognosy Journal, 7, 44-51. https://doi.org/10.5530/pj.2015.1.5

[47] Srinivasan, R., Chandrasekar, M.J.N., Nanjan, M.J. and Suresh, B. (2007) Antioxidant Activity of Caesalpinia digyna Root. Journal of Ethnopharmacology, 113, 284-291. https://doi.org/10.1016/j.jep.2007.06.006

[48] Robbins, R.C. (1980) Medical and Nutritional Aspects of Citrus Bioflavonoids. Chapter 3. In: Citrus Nutrition and Quality, 43-59.

https://doi.org/10.1021/bk-1980-0143.ch003

[49] Pinelo, M., Franco, D., Sineiro, J., Rubilar, M., Sánchez, M., Jerez, M., Costoya, N. and Nunez, M.J. (2008) Polyphenols from Plant Materials: Extraction and Antioxidant Power. Electronic Journal of Environmental, Agriculture and Food Chemistry, 7, 3210-3216.

[50] Antolovich, M., Prenzler, P., Robards, K. and Ryan, D. (2000) Sample Preparation in the Determination of Phenolic Compounds in Fruits. Analyst, 125, 989-1009. https://doi.org/10.1039/b000080i

[51] Soler-Rivas, C., Espín, J.C. and Wichers, H.J. (2000) An Easy and FAST Test to Compare Total Free Radical Scavenger Capacity of Foodstuffs. Phytochemical Analysis, 11, 330-338.

https://doi.org/10.1002/1099-1565(200009/10)11:5<330::AID-PCA534>3.0.CO;2-G

[52] Toh, J.J., Khoo, H.E. and Azrina, A. (2013) Comparison of Antioxidant Properties of Pomelo [Citrus grandis (L) Osbeck] Varieties. International Food Research Journal, 20, 1661-1668.

[53] Ramful, D., Tarnus, E., Aruona, O.I., Bourdon, E. and Bohorun, T. (2011) Polyphenol Composition, Vitamin C Content and Antioxidant Capacity of Mauritian Citrus Fruit Pulps. Food Research International, 44, 2088-2099. 
https://doi.org/10.1016/j.foodres.2011.03.056

[54] Cano, A., Hernandez-Ruiz, J., Garcia-Canovas, F., Acosta, M. and Arnao, M.B. (1998) An End-Point Method for Estimation of the Total Antioxidant Activity in Plant Material. Phytochemical Analysis, 9, 196-202.

https://doi.org/10.1002/(SICI)1099-1565(199807/08)9:4<196::AID-PCA395>3.0.CO; $\underline{2-\mathrm{W}}$

[55] Apak, R., Guclu, K., Ozyurek, M. and Karademir, S.E. (2004) Novel Total Antioxidant Capacity Index for Dietary Polyphenols and Vitamins C and E, Using Their Cupric Ion Reducing Capability in the Presence of Neocuproine: CUPRAC Method. Journal of Agricultural and Food Chemistry, 52, 7970-7981. https://doi.org/10.1021/jf048741x

[56] Mekni, M., Azez, R., Tekaya, M., Mechri, B. and Hammami, M. (2013) Phenolic, Non-Phenolic Compounds and Antioxidant Activity of Pomegranate Flower, Leaf and Bark Extracts of Four Tunisian Cultivars. Journal of Medicinal Plants Research, 7, 1100-1107.

[57] Mortada, M.E., Abdel-Hameed, E.S., Ahmed, W.S. and El-Wakil, E.A. (2008) Non-Phenolic Antioxidant Compounds from Buddleja asiatica. Zeitschrift für Naturforschung C, 63, 483-491. https://doi.org/10.1515/znc-2008-7-803

[58] Umapathy, E., Ndebia, E.J., Meeme, A., Adam, B., Menziura, P., Nkeh-Chungag, B.N. and Iputo, J.E. (2010) An Experimental Evaluation of Albuca setosa Aqueous Extract on Membrane Stabilization, Protein Denaturation and White Blood Cell Migration during Acute Inflammation. Journal of Medicinal Plant Research, 4, 789-795.

[59] Mounnissamy, V.M., Kavimani, S., Balu, V. and Drlin, Q.S. (2008) Evaluation of Anti-Inflammatory and Membrane Stabilizing Properties of Ethanol Extract of Canjera rehedi. Iranian Journal of Pharmacology and Therapeutics, 6, 235-237.

[60] Chaitanya, R., Sandhya, S., David, B., Vinod, K.R. and Murali, S. (2011) HRBC Membrane Stabilizing Property of Roor, Stem and Leaf of Glochidion velutinum. International Journal of Research in Pharmaceutical and Biomedical Sciences, 2, 256-259.

[61] Mellors. A., Tappel, A.L., SawantI, P.L. and Desa, D. (1967) Mitochondrial Swelling and Uncoupling of Oxidative Phosphorylation by Lysosomes. Biochimica et Biophysica Acta (BBA)-Bioenergetics, 143, 299-309.

https://doi.org/10.1016/0005-2728(67)90084-9

[62] Alhakmani, F., Kumar, S. and Khan, S.A. (2013) Estimation of Total Phenolic Content, In-vitro Antioxidant and Anti-Inflammatory Activity of Flowers of Moringa Oleifera. Asian Pacific Journal of Tropical Biomedicine, 3, 623-627. https://doi.org/10.1016/S2221-1691(13)60126-4

[63] Kassim, M., Achoui, M., Mustafa, M.R., Mohd, M.A. and Yusoff, K.M. (2010) Ellagic Acid, Phenolic Acids, and Flavonoids in Malaysian Honey Extracts Demonstrate in Vitro Anti-Inflammatory Activity. Nutrition Research, 30, 650-659. https://doi.org/10.1016/j.nutres.2010.08.008

[64] Masuda, T., Jitoe, A., Isobe, J., Nakatani, N. and Yonemori, S. (1993) Anti-Oxidative and Anti-Inflammatory Curcumin-Related Phenolics from Rhizomes of Curcuma domestica. Phytochemistry, 32, 1557-1560. https://doi.org/10.1016/0031-9422(93)85179-U

[65] Claeson, P., Panthong, A., Tuchinda, P., Reutrakul, V., Kanjanapothi, D., Taylor, W.C. and Santisuk, T. (1993) Three Non-Phenolic Diarylheptanoids with Anti-Inflammatory Activity from Curcuma xanthorrhiza. Planta Medica, 59, 451-454. https://doi.org/10.1055/s-2006-959730 
[66] Claeson, P., Pongprayoon, U., Sematong, T., Tuchinada, P., Reutrakul, V., Soontornsaratune, P. and Taylor, W.C. (1996) Non-Phenolic Linear Diarylheptanoids from Curcuma xanthorrhiza: A Novel Type of Topical Anti-Inflammatory Agents: Structure-Activity Relationship. Planta Medica, 62, 236-240. https://doi.org/10.1055/s-2006-957867

[67] Oyedapo, O.O., Akinpelu, B.A., Akinwunmi, K.F., Adeyinka, M.O. and Sipeolu, F.O. (2010) Red Blood Cell Membrane Stabilizing Potentials of Extracts of Lantana camara and Its Fractions. International Journal of Plant Physiology and Biochemistry, 2, 46-51.

[68] Dodson, R.A., Hinds, T.R. and Vincenzi, F.F. (1987) Effects of Calcium and A23187 on Deformability and Volume of Human Red Blood Cells. Blood Cells, 12, 555-564.

[69] Friederichs, E. and Meiselman, H.J. (1994) Effects of Calcium Permeabilization on RBC Rheologic Behavior. Biorheology, 31, 207-215.

[70] Ahmad, I., Mehmood, Z. and Mohammad, F. (1998) Screening of Some Indian Medicinal Plants for Their Antimicrobial Properties. Journal of Ethnopharmacology, 62, 183-193. https://doi.org/10.1016/S0378-8741(98)00055-5

[71] Eloff, J.N. (1998) Which Extractan Should Be Used for Screening and Isolation of Antimicrobial Components from Plants? Journal of Ethnopharmacology, 60, 1-8. https://doi.org/10.1016/S0378-8741(97)00123-2

[72] Bhakuni, D.S., Dhar, M.L., Dhawan, B.N. and Mehrotra, B.N. (1969) Screening of Indian Plants for Biological Activity, Part II. Indian Journal of Experimental Biology, 7, 250-262. https://doi.org/10.1016/S0168-1605(02)00169-1

[73] Alzoreky, N.S. and Nakahara, K. (2003) Antibacterial Activity of Extracts from Some Edible Plants Commonly Consumed in Asia. International Journal of Food Microbiology, 80, 223-230.

[74] Olano, I., Alonso Paz, E., Cerdeiras, M.P., Fernandez, J., Ferreira, F., Moyna, P., Soubes, M., Vázquez, A., Vero, S. and Bassagoda, M.J. (1996) Screening of the Uruguayan Medicinal Plants for Anti-Microbial Activity. Part II. Journal of Ethnopharmacology, 53, 111-115.

\section{Highlights of the Study}

- We report and compare the anti-oxidant, anti-inflammatory and anti-microbial activities of different solvent fractions of coconut testa.

- The present study documents the maximum extractability of phenolics and flavonoid compounds from CT exclusively in the methanolic fraction and the phenolic content reported to be highest among all previous studies on CT.

- The methanolic fraction containing the phenolics had invariably the highest anti-oxidant activity in almost all assay methods. Anti-oxidant activity was also exhibited by solvent fractions containing the non-polyphenolic compounds.

- The sequential soxhlet extraction process adopted here could be a potential tool of isolating maximum phenolic compounds at least from CT.

- The findings of the study reveal that CT is a rich source of various polyphenolic and non-phenolic natural antioxidants, anti-inflammatory and antimicrobial compounds. 